Marek Dylewski,

Wyższa Szkola Bankowa w Poznaniu

Beata Zofia Filipiak,

Uniwersytet Szczeciński

\title{
Wpływ środków UE dedykowanych małym i średnim przedsiębiorstwom na wielkość akcji kredytowej w sektorze bankowym
}

\author{
IMPACT OF EU FUNDS DEDICATED TO SMALL \\ AND MEDIUM-SIZED ENTERPRISES ON THE SIZE \\ OF LENDING IN THE BANKING SECTOR
}

Małe i średnie przedsiębiorstwa (MŚP), tak jak pozostałe podmioty sfery realnej, aby funkcjonować i rozwijać się, muszq podejmować decyzje zwiazane z wyborem odpowiedniego źródła finansowania, uwzględniajac jego dostępność oraz warunki pozyskania. $W$ artykule wskazano na kierunkowe badania dotyczqce wptywu środków UE na gospodarkę. W badaniach postużono sie nastęujacymi metodami: podstawowe metody analizy szeregów czasowych oraz metody indeksowe stużqce do analizy szeregów, stużqce do określania przyrostu obserwowanego zjawiska $w$ badanym okresie $w$ porównaniu $z$ okresem bazowych (dynamika zmienności). Dokonano analizy alokacji środków UE celem ustalenia, czy majq one istotny wptyw na zmiany wartości akcji kredytowej banków w odniesieniu do sektora MŚP? oraz ustalono, czy wystapity zmiany w jakości portfela kredytowego podmiotów z sektora MŚP? Przeprowadzone analizy miaty za cel przybliżenie odpowiedzi na pytanie, czy środki UE maja wpływ na wielkość akcji kredytowej banków dedykowanej MŚP.

Słowa kluczowe: polityka publiczna, środki UE, akcja kredytowa, małe i średnie przedsiębiorstwa

\section{Wprowadzenie}

Małe i średnie przedsiębiorstwa (MŚP), tak jak pozostałe podmioty sfery realnej, aby funkcjonować i rozwijać się, muszą podejmować decyzje związane $\mathrm{z}$ wyborem odpowiedniego źródła finansowania, uwzględniając jego dostępność oraz warunki pozyskania [Filipiak, Ruszała 2009]. W sektorze MŚP, w szczególności ze względu na ograniczone zasoby materialne, wielkość podmiotu i często formę ewidencji księgowej, możliwości pozyskania kapitału, są ograniczone. Wraz z zachodzącymi zmianami związanymi z przystąpieniem Polski do Unii Europejskiej (UE), nowym dostępnym źródłem stały się fundusze unijne (środki UE).

Celem opracowania jest poszukiwanie odpowiedzi na pytanie, czy środki UE mają znaczący wpływ na wielkość akcji kredytowej banków dedykowanej MŚP? Przeprowadzona analiza ma charakter poznawczy, gdyż w literaturze przedmiotu brak jest dokładnych badań i danych potwierdzających wpływ środków UE dedykowanych 
MŚP na wielkość akcji kredytowej w sektorze bankowym. Opracowanie tym samym ma na celu wskazanie na pewne tendencje i zależności (badanie wstępne), które będą wymagały dokładnego zbadania i pogłębienia (badanie pogłębione, ustalające dokładne zależności).

\section{Wyniki badań}

\section{Wpływ środków Unii Europejskiej na gospodarkę}

Skuteczność przy wydawaniu funduszy unijnych to, wydawałoby się, rzecz kluczowa. Wiele się wskazuje na ten temat $\mathrm{w}$ literaturze przedmiotu wskazując na alokacje środków UE w kolejnych perspektywach finansowych (wykres 1) oraz oczekiwania związane z ich zastosowaniem tzw. wskaźniki i mierniki rezultatu dla każdej z osi programów UE. [Misiag i in. 2013; Sosińska-Wit 2014; Gadziński 2014; SorychtaWojsczyk, Musioł-Urbańczyk 2016; Śliwka 2016] Wskazuje się, że polska gospodarka w perspektywie UE 2007-2013, zanotowała wiele korzyści zarówno w skali mikro, jak i makro, które były efektem dużego napływu inwestycji, jak również środki UE złagodziły niewątpliwie oddziaływanie kryzysu finansowego. Obecnie polska gospodarka stanęła przed szansą, którą daje potencjalny napływ środków w obecnej perspektywie UE 2014-2020.

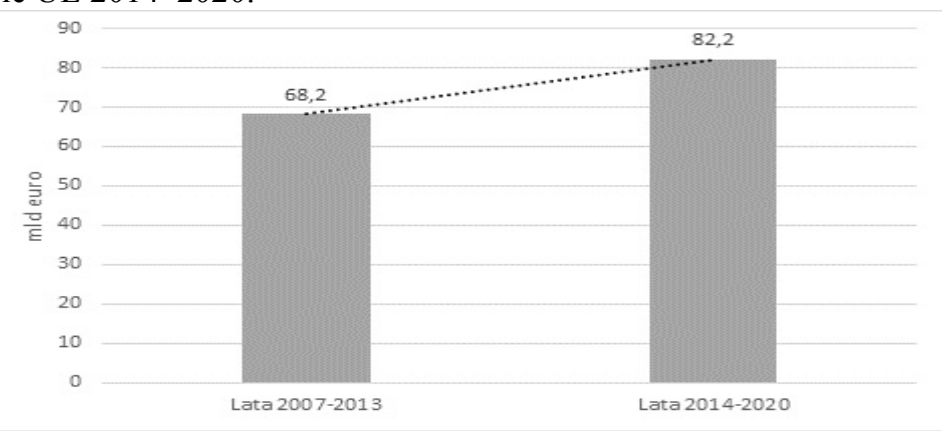

Wykres 1. Środki UE na realizację polityki spójności (w mld euro)

Źródło: opracowanie własne na podstawie: Fundusze Unijne w latach 2014-2020, PKO Bank Polski (2015), www.pkobp.pl/korporacje-i-samorzady/fundusze-unijne/fundusze-unijne-w-latach-2014 -2020/funduszeunijne-w-latach-2014-2020 (data dostępu: 02.09.2018); EU Funds in Central and Eastern Europe. Progress Report 2007-2014, KPMG, (2015),

www.kpmg.com/PL/pl/IssuesAndInsights/ArticlesPublications/Documents/2015/

EU-Funds-in-Central-and-Eastern-Europe-2007-2014.pdf, s. 44 (data dostępu: 02.09.2018); [Sprawozdanie, 2015]; [Realizacja programów..., 2018]

Należy wskazać, że brakuje również konkretnych informacji o ich wpływie na gospodarkę, oraz o konkretnych mierzalnych celach, jakie mają być osiagnięte. Do najbardziej eksponowanych należą te informacje, które dotyczą wniosków i projektów wspartych, oddziaływania na rynek w postaci liczby miejsc pracy, które zostały wsparte, dofinansowanych projektów B+R, czy oddziaływania na kapitał ludzki. ${ }^{1}$ Wszystkie dokumenty i informacje ewoluują, a prowadzone badania najczęściej

\footnotetext{
${ }^{1}$ Dane podawane są na Portalu Funduszy Europejskich: https://www.funduszeeuropejskie.gov.pl/strony/ofunduszach/efekty-funduszy-europejskich/efekty-lata-2014-2020/ [dostęp: 30.10.2018]
} 
skupione są wokół wpływu funduszy UE na PKB i zatrudnienie [Kehagia 2013; Claudiu, Goyeau 2013; Rinaldi, Núńez 2017; Kaiser, Prange-Gstöhl 2017]. Również występujące poglądy, że fundusze UE nie przyczyniają się wystarczająco do rozwoju Polski, nie są poparte konkretnymi liczbami (wyjątkiem są dane i prognozy dotyczące wydatków na badania i rozwój w stosunku do PKB). [Czepiel 2016]

W pierwszych latach członkostwa Polski w Unii Europejskiej (2004-2006) wpływ Funduszy UE na gospodarkę Polski był nieznaczny, chociaż już w 2007 r. zaobserwowano silną korelację między inwestycjami finansowanymi $\mathrm{z}$ funduszy unijnych, a głównymi wskaźnikami makroekonomicznymi, natomiast także w tym czasie nastapił wzrost nakładów brutto na środki trwałe [Rutkiewicz 2011, s. 107]. Należy podkreślić, że przeprowadzone badania wskazuja, że wpływ środków UE w pierwszych latach obowiazzywania interwencji był stosunkowo nieznaczny, gdyż wiązał się z niewielkim w ujęciu zaangażowaniem środków tym okresie.

Oszacowano również, że największy wzrost dynamiki PKB przypada na lata 20102014, a ponadto nastąpił również silny wzrost inwestycji [Rutkiewicz 2011, s. 108-110]. Oddziaływanie funduszy nasila się wraz ze wzrostem intensywności absorpcji środków UE, a jego maksimum przypada na ostatnie lata perspektywy, po czym słabnie. Zachowanie wyższego poziomu PKB względem scenariusza bazowego byłoby możliwe, przy innych czynnikach niezmienionych, przy założeniu kontynuacji absorpcji środków polityki spójności na dotychczasowym poziomie lub też gdyby środki te zostały zastapione adekwatnymi środkami własnymi.[Kaczor, Soszyński 2011; Ancyparowicz 2017] Rośnie również rola środków UE w zakresie poprawy jakości życia mieszkańców. [Czudec 2017, s. 46] Ta rola środków UE, jako czynnika zmieniającego pozytywnie regiony i społeczeństwo, łagodzącego ubóstwo i wspierającego wyrównywanie różnic i szans społecznych jest niezaprzeczalna.

Unia Europejska, poprzez różne programy, stara się wspierać małe i średnie przedsiębiorstwa na rynkach krajowych jak i wspólnym rynku europejskim. Wspieranie MŚP należy do najważniejszych zadań samorządu terytorialnego w dziedzinie lokalnego rozwoju gospodarczego. System wspierania rozwoju MŚP obejmuje różnego rodzaju instrumenty. Do najczesściej wymienianych zalicza się instrumenty finansowe i niefinansowe. Polscy przedsiębiorcy mają dostęp do wsparcia bezpośredniego (w szczególności za pomocą dotacji i subwencji) i pośredniego za pomocą różnych programów, które są zarządzane na szczeblach centralnym i regionalnym. Do takich programów zaliczają się programy finansowane z Funduszy Strukturalnych UE. Natomiast do instrumentów pośrednich można zaliczyć między innymi narzędzia ułatwiające dostępność do kredytów i pożyczek. [Leoński 2015, s. 122]

Jako jedną z najważniejszych barier wpływających na rozwój MŚP uważa się barierę kapitałową tj. ograniczenia $\mathrm{w}$ dostępie do zewnętrznych źródeł finansowania. [Rossi 2014, Sobolewski 2018] Utrudniony dostęp do tych źródeł wynika przede wszystkim ze stosunkowo niskiego poziomu majątku oraz generowania niskich dochodów, niestanowiących często wystarczającego zabezpieczenia gwarantującego zwrot pozyskanego kapitału.[Filipiak, Ruszała 2008, Sobolewski 2018; Raport 2018] Jest to także czynnik wpływający na niewielkie możliwości pozyskania środków, np. $\mathrm{w}$ formie emisji akcji lub obligacji. Równie istotnym ograniczeniem w pozyskaniu kapitału jest brak konieczności sporządzania przez większość małych i średnich firm sprawozdań finansowych pomagających określić sytuację ekonomiczno-finansową 
(ewidencja oparta na zapisie jednostronnym). Bariery kapitałowe mogą także wiązać się z wysokimi kosztami pozyskania określonych form finansowania, np. kredytów (oprocentowanie, opłaty, prowizje, ubezpieczenia, koszty dodatkowych zabezpieczeń). [Gorczyńska 2014, s. 338]

Bariera kapitałowa może pojawiać się w różnym natężeniu w poszczególnych fazach cyklu życia przedsiębiorstwa. [Gorczyńska 2014, s. 338]. MŚP poszukując kapitału, wobec braku lub ograniczonych możliwości skorzystania z kredytu, czy też możliwości pozyskania środków bezpośrednio z rynku finansowego, wykorzystują instrumenty pośrednie $\mathrm{w}$ postaci pożyczek $\mathrm{i}$ poręczeń kredytowych oraz dotacji i subwencji (w postaci pozyskanych projektów współfinansowanych z programów UE), które nie są pozyskiwane $\mathrm{z}$ rynku bankowego, ale $\mathrm{z}$ instytucji wsparcia biznesu wykorzystujących w znaczącej części środki UE.

Zmienia się struktura kapitału w MŚP $i$ jest ona inna niż $w$ dużych przedsiębiorstwach, na co wskazują badania prowadzone w różnych krajach [van'tHul 2014; Raport 2018] W literaturze przedmiotu wskazuje się również, że struktura kapitału zależy ona od wielu czynników, w szczególności takich jak: na poziomie krajowym, na poziomie branżowym i na poziomie przedsiębiorstwa.[Bates, 1971; Titman and Wessels, 1988; Ang, 1991; Petersen, Rajan, 1994; van'tHul 2014] Badania, odnoszace się do czynników krajowych i na poziomie przedsiębiorstw, sugerują obecność różnic w strukturze kapitałowej MŚP i dużych firm oraz że wskaźnik dźwigni jest funkcją kilku cech charakterystycznych przedsiębiorstwa [van'tHul 2014; Rossi 2014].

Znaczny wpływ na zmianę struktury kapitału finansującego MŚP mają środki UE dystrybuowane na konkretne cele. $Z$ jednej strony środki te pozwalają wyrównywać różnice $\mathrm{w}$ rozwoju przedsiębiorstw $\mathrm{z}$ sektora MŚP w Polsce $\mathrm{z}$ wysoko rozwiniętymi krajami UE. Z drugiej strony podwyższając konkurencyjność polskich MŚP poprzez dostęp do niżej oprocentowanych pożyczek, jak również, poprzez dostęp do pieniądza dotacyjnego (w ramach projektów UE), zaburzają rynek pieniężny i kapitałowy.

MŚP mając na rynku dostęp do kapitału, który nie jest oprocentowany lub też jego cena jest znacznie niższa od pieniądza oferowanego przez banki i instytucje finansowe, będą starać się pozyskać kapitał o korzystniejszej cenie. Jak wykazują badania, procedury bankowe, jak również wymagania proceduralne stawiane przez banki i instytucje finansowe, stanowią znaczące ograniczenie dla MŚP w skorzystaniu z oferty tych instytucji.[European Small..., 2018]

Niezaprzeczalnie środki UE wywierają wpływ na PKB, na rozwój lokalny i regionalny, wywierają również wpływ na konkurencyjność MŚP. Niewątpliwie zaburzają rynek zarówno po stronie popytu na pieniądz, jak i jego podaży. Nie wykazano w literaturze przedmiotu bezpośredniego związku między środkami UE, a polityką banków wobec MŚP, biorąc pod uwagę strukturę polskich przedsiębiorstw ${ }^{2}$.

W perspektywie finansowej 2007-2013 jednym z celów było podniesienie innowacyjności i konkurencyjności przedsiębiorstw, w jego ramach poprawa otoczenia funkcjonowania przedsiębiorstw $\mathrm{i}$ ich dostępu do zewnętrznego finansowania dzięki stworzeniu instrumentów służących budowie przyjaznego otoczenia instytucjonalnego

\footnotetext{
${ }^{2}$ Polski sektor przedsiębiorstw jest zdominowany przez mikroprzedsiębiorstwa, których udział w strukturze wszystkich przedsiębiorstw wynosi aż $96,2 \%$. Na przestrzeni ostatnich lat nastąpił wzrost liczby mikrofirm. [Raport 2018, s. 8]
} 
i kapitałowego, prowadzących do rozwoju istniejących i powstawania nowych przedsiębiorstw, a w szczególności MŚP. W tej perspektywie założono wykorzystanie instrumentów finansowych $\mathrm{w}$ procesie wdrażania Funduszy UE poprzez odejście od tradycyjnego dotacyjnego wsparcia beneficjentów na rzecz wsparcia pośredników finansowych (np. funduszy pożyczkowych, poręczeniowych czy funduszy miejskich), którzy transferują środki do ostatecznych odbiorców. Mowa tu przede wszystkim o inicjatywach JEREMIE i JESSICA. Na wsparcie badań i rozwoju technologicznego, innowacji i przedsiębiorczości przeznaczono $\mathrm{w}$ tej perspektywie środki w wysokości 11,6 mld euro, $\mathrm{z}$ czego na inwestycje w przedsiębiorstwa bezpośrednio związane z dziedziną badań i innowacji 28,5 mld zł. Natomiast wsparcie MŚP w ramach instrumentów finansowych wyniosło na koniec okresu wyniosło 5,676 mln zł, przy czym w ramach instrumentów pożyczkowych 4,015 $\mathrm{mln}$ zł.[Sprawozdanie, 2015] Należy podkreślić, że po spłacie instrumentów finansowych są one dalej angażowane na ten sam cel. Oznacza to, że w nowej perspektywie uzupełnią one środki przeznaczone na wsparcie MŚP. Szacunkowe wsparcie w perspektywie 2014-2020 dedykowane MŚP zamyka się kwotą 13,491 mld zł (programy krajowe i RPO województw).[Realizacja programów..., 2018] Duża część z tej puli będzie (i już jest) kierowana do MŚP jako instrumenty finansowe. Na tym etapie nie można jeszcze precyzyjnie wskazać docelowej wielkości, ale na pewno trzeba wskazać, że będzie ona uzupełniana o środki ze starej perspektywy. Tym samym środki UE w sposób istotny wpływaja na zapotrzebowanie kapitałowe ze strony sektora MŚP, ponieważ wsparcie odbywa się bezpośrednio poprzez dofinansowywanie projektów oraz pośrednio poprzez instrumenty finansowe. Nie należy przy tym zapominać, że dofinansowanie projektów ze środków UE będzie powodowało konieczność zaangażowania wkładu własnego.

Problemem badawczym jest ustalenie, czy występuje bezpośredni związek (zależność) między środkami UE a polityką banków wobec MŚP. Jeżeli ta zależność znajdzie potwierdzenie, to koniecznym będzie ustalenie, na ile środki UE wpływają na wielkość akcji kredytowej w sektorze bankowym, zmiany polityki bankowej w odniesieniu do standardów oceny zdolności kredytowej i ceny pieniądza wyrażoną podstawową stopa kredytu lombardowego NBP oraz rynku międzybankowym. Konieczne jest też poszukiwanie odpowiedzi na pytanie: czy występuje zmiana i dostosowanie oferty bankowej do występującej ceny na pieniądz na rynku spowodowanej wzrostem dostępności środków UE dedykowanych MŚP?

\section{Material badawczy i podejście badawcze}

Podstawę informacyjną badań stanowily dane statystyczne z lat 2010-20173, zgromadzone poprzez NBP, które stanowią statystykę monetarną i finansową odnoszącą się do danych opisujących sektor bankowy.[www.1] Wykorzystane dane stanowią zagregowane dane banków i oddziałów instytucji kredytowych na temat wartości należności według podziału produktowego, podmiotowego oraz podziału portfelowego. Dane dotyczące należności ogółem prezentowane są dla całego sektora bankowego, natomiast informacje dotyczące odpisów oraz należności z utratą wartości obejmują sektor finansowy oraz niefinansowy. Powyższe dane stanowią podstawowe cechy diagnostyczne opisujące sektor bankowy.

${ }^{3}$ Za kata 2009 i 2018 istnieją niepełne dane. 
Do analizy zmian polityki kredytowej banków wykorzystano dane pochodzące z badań ankietowych NBP przeprowadzane wśród przewodniczących komitetów kredytowych kilkudziesięciu największych banków działających na polskim rynku [www. 2], które są publikowane co kwartał. Celem ankiety NBP jest określenie kierunku zmian polityki kredytowej, tj. kryteriów i warunków udzielania kredytów, a także zmian popytu na kredyty w polskim systemie bankowym. Uzasadnieniem wykorzystania wyników badan ankietowych prowadzonych przez NBP jest ich stosunkowo wysoka wiarygodność. Nie należałoby się spodziewać, że taka sama ankieta przeprowadzona przez autorów dałaby inne rezultaty niż te wskazane wyżej. Ponadto wykorzystano dane dotyczące zmian stóp procentowych NBP w latach 2009-2018, w celu ustalenia zależności między zmianami stóp procentowych $\mathrm{i}$ ich wpływem na zmianę polityki kredytowej banków [www.3].

Wielkość środków UE dedykowanych MŚP ustalono w oparciu o oficjalne dane sprawozdawcze [Sprawozdanie z realizacji..., 2015] oraz prognozy i sprawozdania dotyczące alokacji środków w perspektywie 2014-2020 według celów tematycznych i kategorii interwencji [Realizacja programów..., 2018]. Jako okres badawczy przyjęto lata 2009-2017. Okres ten przyjęto z uwagi na dostępność danych NBP oraz danych o alokacji środków UE.

Badanie wpływu środków UE dedykowanych MŚP na wielkość akcji kredytowej w sektorze bankowym oparto na następującym podejściu badawczym:

- Ustalenie wielkość środków UE dedykowanych MŚP w dwóch perspektywach finansowych. Dane te posłużą do wnioskowania, czy środki UE są w stanie stanowić alternatywny kapitał finansujący długoterminowe i krótkoterminowe zapotrzebowanie MŚP?

- Ustalenie wielkości, struktury oraz dynamiki zmian akcji kredytowej banków. Analizie poddano wielkość akcji kredytowej ogółem oraz w podziale na kredyty w PLN i w walutach wymienialnych. Dane te posłużą do wnioskowania, czy istotnie zmieniła się wielkość akcji kredytowej w odniesieniu do sektora MŚP?

- Ustalenie zmian w jakości portfela kredytowego podmiotów sektora MŚP. Dane te posłużą do wnioskowania dotyczącego zmian w strukturze absorbowanego kapitału przez MŚP i w zakresie ustalenia skłonności banków do zmiany polityki kredytowej wobec podmiotów sektora MŚP.

- Ustalenie, jak zmienia się polityka kredytowa banków. Dane te wskażą, czy sektor bankowy, pod wpływem zwiększenia dostępności alternatywnego kapitału, jakim są środki UE, zmienia (rozluźnia lub zacieśnia) politykę kredytową wobec MŚP. W badaniu przyjęto następujące pytania badawcze:

1. czy środki UE mają istotny wpływ na zmiany polityki kredytowej portfela kredytowego sektora bankowego?

2. czy zmieniła się wartość akcji kredytowej banków w odniesieniu do sektora MŚP?

3. czy wystąpiły zmiany w jakości portfela kredytowego podmiotów z sektora MŚP?

W celu uzyskania odpowiedzi na zadane pytania badawcze posłużono się następującymi metodami: podstawowe metody analizy szeregów czasowych oraz metody indeksowe służące do analizy szeregów, służące do określania przyrostu obserwowanego zjawiska $\mathrm{w}$ badanym okresie $\mathrm{w}$ porównaniu $\mathrm{z}$ okresem bazowych (dynamika zmienności). 


\section{Wyniki badań}

Prowadząc analizę porównawczą dotycząca prowadzonej akcji kredytowej w bankach opisanych za pomocą przyjętych cech diagnostycznych dokonano analizy danych źródłowych (bazy danych NBP dotyczącej statystyki monetarnej i finansowej), w oparciu o którą wskazać można na następujące wnioski:

1. Analiza udziału procentowego MŚP w akcji kredytowej banków dla przedsiębiorstw nie wykazuje znaczących zmian. Cechą charakterystyczną jest nieznaczny wzrost udzielonych kredytów MŚP w roku 2011 i nieznacznie utrzymujący się wzrost w 2012 r. (po czym następuje spadek do poziomu sprzed roku 2011) przez sektor bankowy oraz widoczna jest w końcówce 2014 roku tendencja spadkowa akcji kredytowej dedykowanej MŚP. Wzrost akcji kredytowej 2011 można wytłumaczyć zwiększoną potrzebą absorpcji środków UE, gdyż podmioty sektora MŚP musiały znaleźć wkład własny potrzebny do realizacji projektów współfinansowanych ze środków UE, jak również potrzebowały środków finansowych na prefinansowanie tychże projektów. Na lata 2011 - 2012 przypada największa absorpcja środków UE tuż przed kończącą się perspektywą finansową UE 2007-2013. Można również wskazać, że okres 2013-2014 jest tym okresem, gdzie kończy się wpływ perspektywy finansowej 2007-2013, a nowa perspektywa 2014-2020 jeszcze nie została uruchomiona, a przedsiębiorcy odczuwają jeszcze finansowe skutki kończącej się perspektywy. Wskazane tendencje zaprezentowano na wykresie 2. Analiza wykazała, że większe wahania występują w odniesieniu do kredytów walutowych. Krzywa udziału procentowego MŚP w akcji kredytowej banków dla przedsiębiorstw ogółem i krzywa procentowego MŚP w akcji kredytowej banków dla przedsiębiorstw w PLN wykazują niemal identyczną tendencję. W krajach UE, szczególnie tzw. starych krajach UE jest on na dużo niższym poziomie i średnio dla UE nie przekracza $20 \%$. Jedynie w Portugalii i Hiszpanii zbliża się do 45\%.[European 2018]

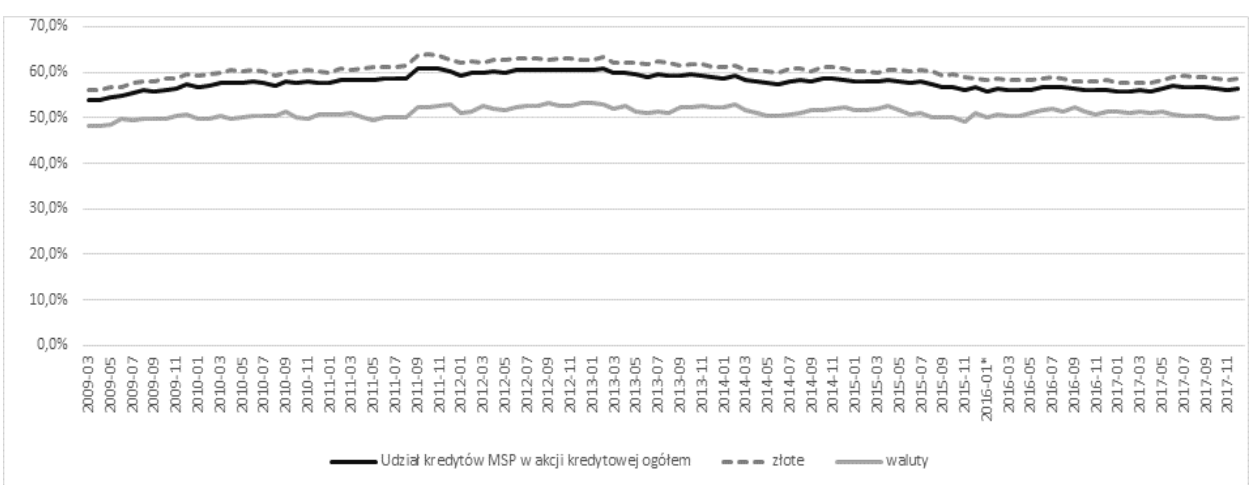

Wykres 2. Udział \% MŚP w akcji kredytowej banków dla przedsiębiorstw Źródło: opracowanie własne na podstawie danych [www.1]

2. W bankach nie jest widoczne ograniczanie akcji kredytowej dla MŚP wraz ze wzrostem podstawowych stóp procentowych NBP. Praktycznie nie istnieje silna zależność między poziomem stóp procentowych, a wielkością akcji kredytowej 
banków dla MŚP (wykres 3). Od 2010 roku mimo wzrostu stóp procentowych, i ich spadku od 2013 rośnie wartość udzielonych kredytów dla MŚP. Podobna tendencja miała miejsce $\mathrm{w}$ UE, przy spadkach stóp procentowych nie zanotowano istotnego wzrostu wolumenu kredytów zarówno w stosunku do dużych przedsiębiorstw jak MŚP.[European 2018]

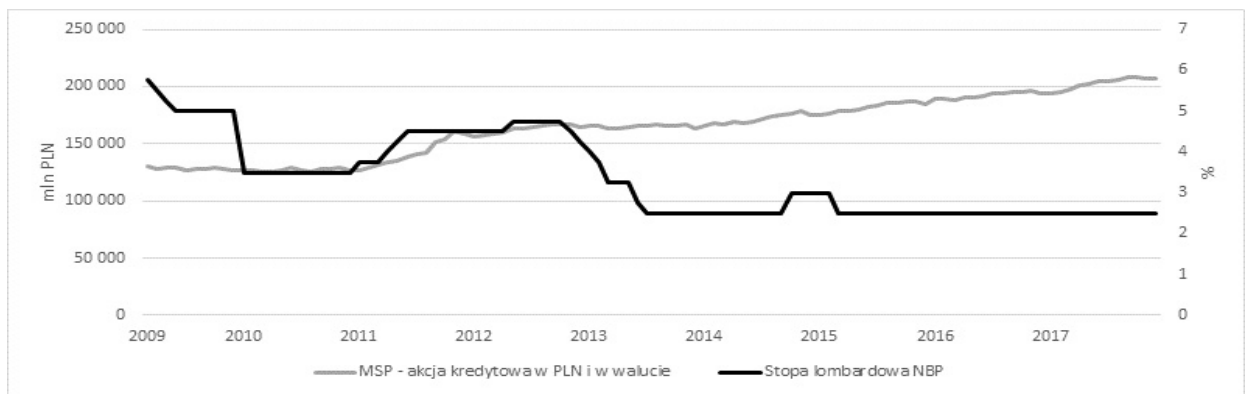

Wykres 3. Relacja między akcją kredytową banków dla sektora MŚP a stopą lombardową NBP Źródło: opracowanie własne na podstawie danych [www.1 i www.3].

3. Analiza dynamiki zmian w zakresie wartości prowadzonej przez banki akcji kredytowej dedykowanych pomiotom sektora MŚP wskazuje na nieznaczne wahania, które w analizowanym okresie słabną. Widoczne są spadki w zakresie akcji kredytowej przypadające na koniec perspektywy finansowej 2007-2013, a zwłaszcza na początku nowej perspektywy 2014-2020 (wykres 4). W nowej perspektywie pojawiły się znaczne środki dedykowane MŚP, jako alternatywne finansowanie (zwłaszcza dostępne w formie funduszy pożyczkowych i poręczeń kredytowych) oraz następował stopniowy powrót do obiegu środków starej perspektywy zaangażowanych $\mathrm{w}$ instrumenty finansowe.

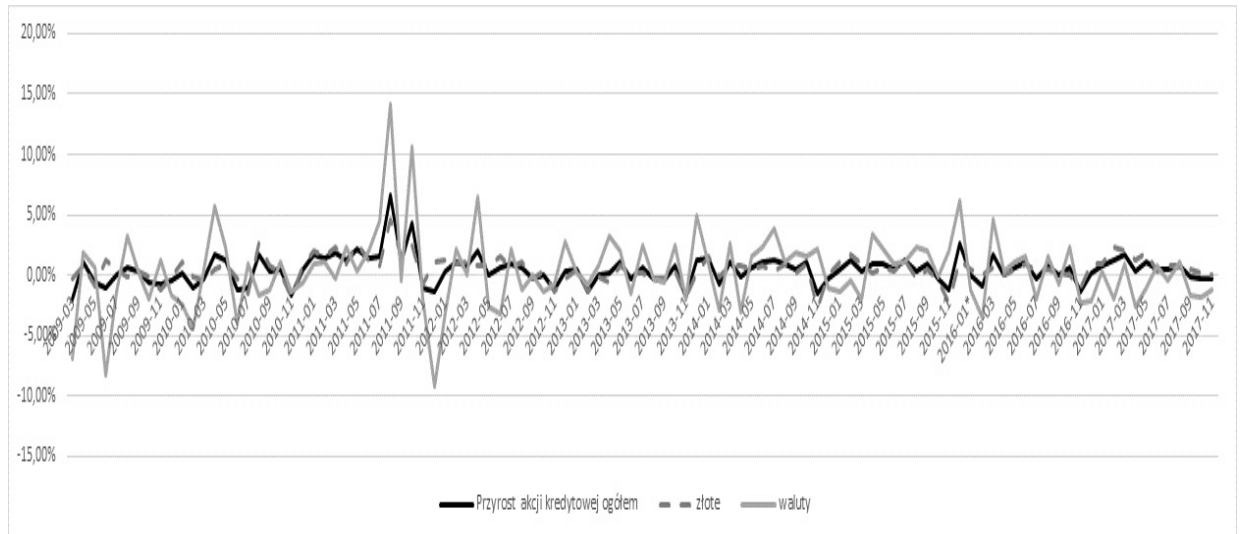

Wykres 4. Dynamika zmian w akcji kredytowej banków dla przedsiębiorstw z sektora MŚP Źródło: opracowanie własne na podstawie danych [www.1].

4. W analizowanym okresie widoczny jest stopniowy, choć niewielki wzrost odpisów z tytułu kredytów o obniżonym standardzie ( $\mathrm{z}$ dużym prawdopodobieństwem 
wystapienia w przyszłości strat). Oznacza to, że pogarsza się jakość portfela kredytowego banków. Wzrost ten przypada na okres od 2013 do 2015, a po roku 2015 udział ten spada. Oznacza to, że w momencie nałożenia się środków z dwóch perspektyw UE jakość portfela kredytowego banków nieznacznie się pogorszyła. Od roku 2016 udział odpisów wyraźnie się zmniejsza, pomimo tendencji w łagodzeniu kryteriów udzielania kredytów MŚP. Te tendencje raczej wynikają z dobrej koniunktury na rynku, niż faktycznego wpływu środków UE i wsparcia dla sektora MŚP.

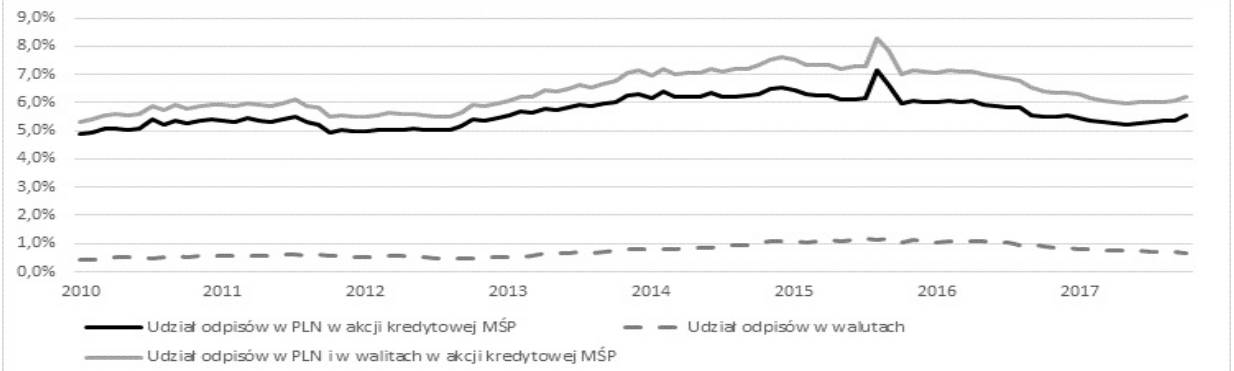

Wykres 5. Udział odpisów kredytów udzielonych MŚP w akcji kredytowej banków dla przedsiębiorstw z sektora MŚP

Źródło: opracowanie własne na podstawie danych [www.1].

Analiza ankiety przeprowadzanej wśród przewodniczących komitetów kredytowych kilkudziesięciu największych banków działających na polskim rynku pozwoliła na ustalenie zmian w polityce kredytowej banków dedykowanej przedsiębiorstwom, a w szczególności sektorowi MŚP.

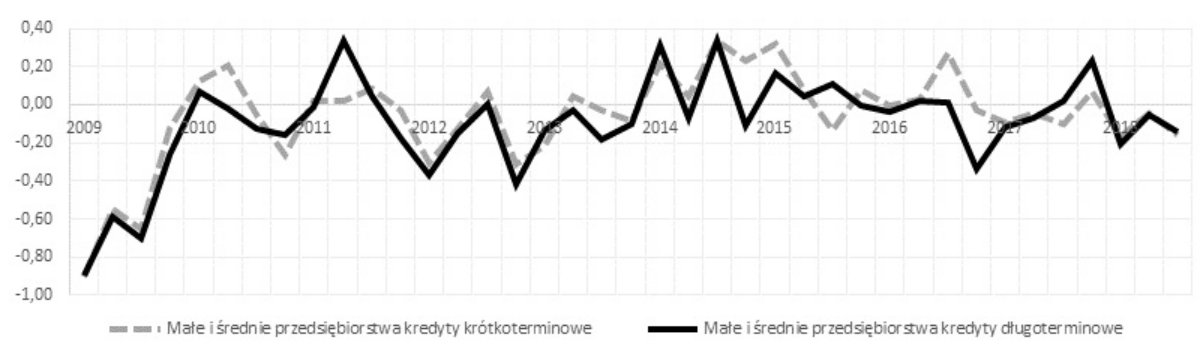

Wykres 6. Zmiana kryteriów banków w zakresie udzielania kredytów dla MŚP Źródło: opracowanie własne na podstawie danych [www.2]

Na wykresie 6 zaprezentowano analizę zmian kryteriów udzielania kredytów dla MŚP w podziale na kredyty bieżące i inwestycyjne. Ujemne wartości oznaczają tendencję do zaostrzania kryteriów przez banki w analizowanym okresie. Widoczna jest tendencja łagodzenia kryteriów udzielania kredytów, która wyraźnie utrzymuje się w okresie programowania przypadającym od 2014 r. Można dodać, że odmienna sytuacja odnotowana została w krajach UE ogółem. Widoczne jest stopniowe 
zaostrzanie polityki kredytowej wobec sektora MŚP, ale także wobec dużych przedsiębiorstw. Tendencja ta widoczna jest od roku 2014, czyli zbieżna z końcem poprzedniej perspektywy UE. Wsparcie środkami UE może niejako wypychać lepsze firmy z dobrymi pomysłami z sektora bankowego do instytucji wspierających MŚP. Dwa główne czynniki łagodzenia polityki kredytowej to konkurencja na rynku bankowym oraz konkurencja spoza tego sektora.[European 2018]

$\mathrm{Na}$ wykresie 7 zaprezentowano analizę zmian popytu na kredyt ze strony MŚP. Dodatnie wartości oznaczają wzrost popytu. O ile w okresie przypadającym na perspektywę lat 2007-2013 obserwowany jest wzrost popytu na kredyt ze strony MŚP, ale wykazujący wahania, to w okresie od 2014 widoczna jest słabnąca tendencja zarówno w zakresie kredytów krótkoterminowych, a zwłaszcza długoterminowych (inwestycyjnych). Można powiedzieć, że znaczące środki UE skierowane do podmiotów sektora MŚP mogły wpłynąć na zmianę struktury kapitału finansującego działalność tych podmiotów.

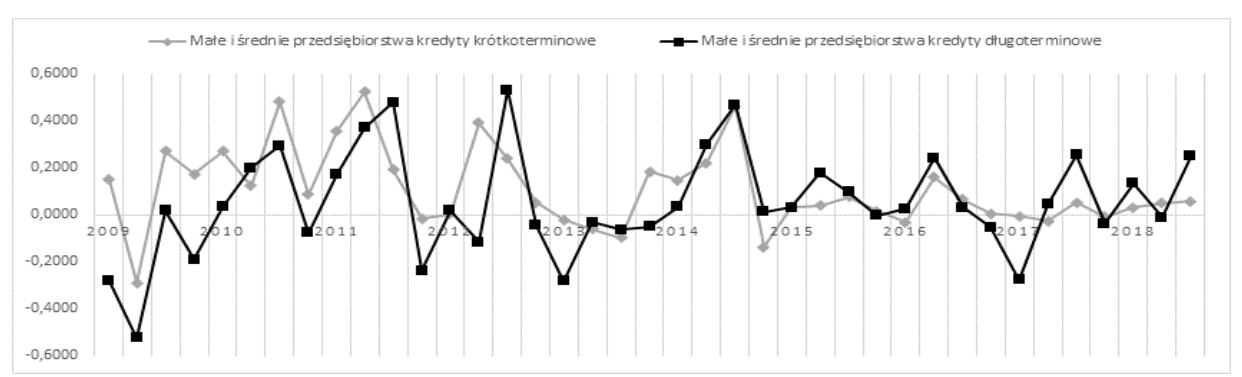

Wykres 7. Zmian popytu na kredyt

Źródło: opracowanie własne na podstawie danych [www.2]

Na wykresie 8 zaprezentowano analizę przyczyn zmian polityki kredytowej banków. Wartości dodatnie oznaczają że dany czynnik oddziaływał na wzrost popytu, ujemny - na spadek. Znaczącymi przyczynami zmian są zapotrzebowanie na finansowanie zasobów i kapitału obrotowego oraz zapotrzebowanie na finansowanie środków trwałych. Te cele zazwyczaj odpowiadają projektom i programom, na które dedykowane są środki UE. Widoczny jest również wpływ alternatywnych źródeł finansowania na zmiany popytu na kredyt. 


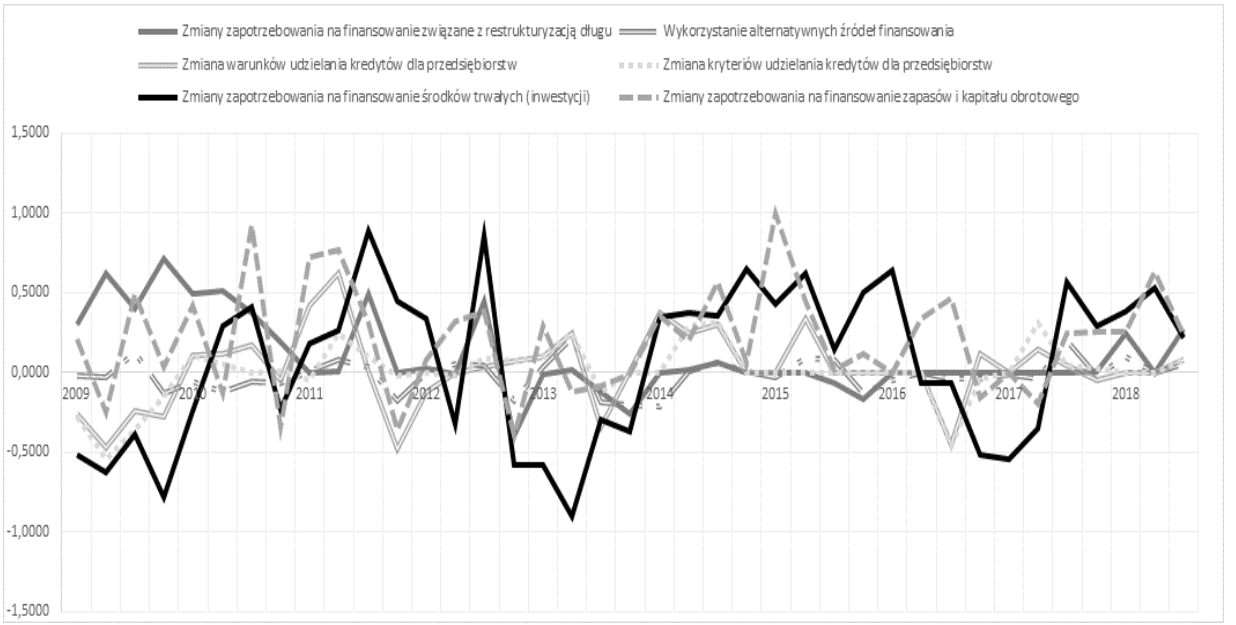

Wykres 8. Przyczyny zmian popytu na kredyt

Źródło: opracowanie własne na podstawie danych [www.2].

$\mathrm{Na}$ wykresie 9 zaprezentowano analizę przewidywanych zmian polityki kredytowej. Dodatnie kształtowanie wartości zaprezentowanych na wykresie oznacza oczekiwane złagodzenie polityki kredytowej. Widoczna tendencja spadkowa oznacza niekorzystne tendencje zmian polityki kredytowej dla podmiotów sektora MŚP. Tym samym będą one poszukiwały alternatywnych źródeł finansowania, których należy upatrywać w dotacjach na projekty współfinansowane ze środków UE, jak również w formie łatwiej dostępnych pożyczek $\mathrm{z}$ funduszy pożyczkowych, których źródłem zasilania są najczęściej środki UE.

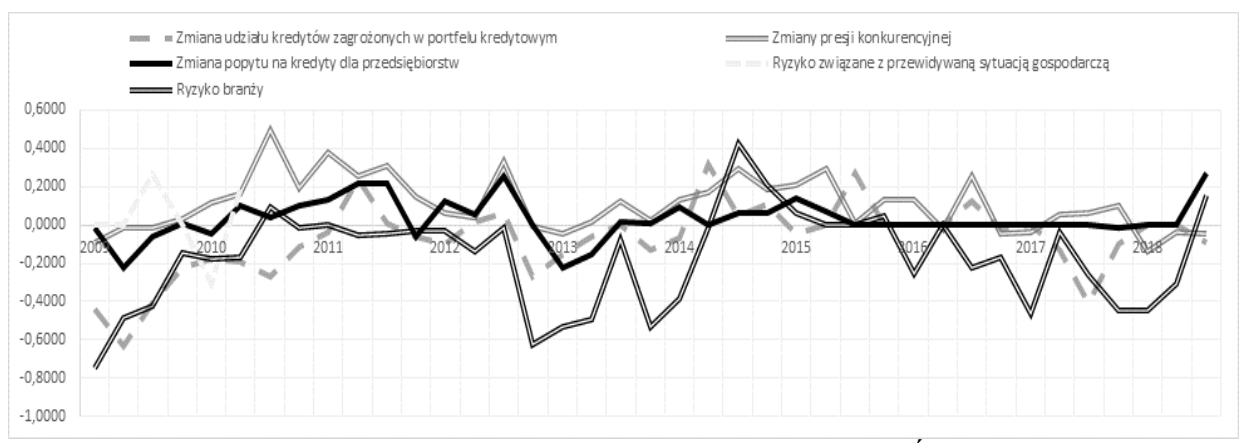

Wykres 9. Przewidywane kierunki zmian polityki kredytowej wobec MŚP Źródło: opracowanie własne na podstawie danych [www.2].

\section{Podsumowanie i wnioski}

Wstępna analiza problemu badawczego wskazuje, że środki UE mogą wpłynąć na wielkość akcji kredytowej w sektorze bankowym oraz na zmiany polityki kredytowej odniesieniu do kredytobiorców. Banki dostrzegają zmiany popytu na środki ze strony podmiotów sektora MŚP. Widoczne jest też łagodzenie polityki kredytowej banków 
wobec podmiotów sektora MŚP. Z drugiej strony MŚP poszukują łatwiejszego dostępu do kapitału, dzięki któremu mogłyby się rozwijać. Można się spodziewać istotniejszego wpływu środków UE kierowanych jako wsparcie sektora MŚP, zarówno jako instrumentów finansowych jak i dofinansowanie przedsięwzięć w nowej perspektywie finansowej 2014-2020. Co należy podkreślić, wsparcie to będzie powiększone przez środki instrumentów finansowych wracających do obiegu po ich spłatach. Ocena łącznego wpływu wsparcia MŚP w obecnej perspektywie finansowej UE będzie możliwa bliżej jej końca, $\mathrm{z}$ uwzględnieniem także zasady $\mathrm{n}+3$. Wtedy środki UE wspierające przedsiębiorstwa sektora MŚP (także te środki obejmujących instrumenty finansowe) na stałe zostaną w obiegu finansowym - łącznie będą to środki z perspektyw 2007-2013 oraz 2014-2020. Środki te nie mogą być wykorzystane na inny cel niż wsparcie sektora MŚP. Ten fakt sektor bankowy będzie musiał uwzględnić w swoich politykach kredytowych, zwłaszcza w sytuacji dużej nadpłynności tego sektora. Zmultiplikowane środki z dwóch perspektyw, angażowane jako instrumenty finansowe, mogą istotnie wpływać na efektywność działalności sektora bankowego i jego politykę kredytową. Tym samym potwierdza się, że występuje związek (zależność) między środkami UE a polityką banków wobec MŚP, jednakże, aby odpowiedzieć na pytanie, czy jest on istotny i jaka jest siła tego wpływu, konieczne jest przeprowadzenie pogłębionych badań $\mathrm{w}$ tym zakresie, także $\mathrm{z}$ uwzględnieniem innych krajów UE oraz czynników mogących mieć wpływ na politykę kredytową banków, szczególnie w zakresie restrykcyjności standardów oceny zdolności kredytowej.

\section{Bibliografia}

Albulescu C., Goyeau. D.: EU Funds Absorption Rate and the Economic Growth, Timisoara Journal of Economics and business, 6 (20)/2013

Ancyparowicz, G.: Wpływ funduszy strukturalnych Unii Europejskiej na inwestycje i wzrost polskiej gospodarki. Ekonomiczne Problemy Usług, nr 4 (129)/2017, s. 5-19.

Ang, J.S.: Small business uniqueness and the theory of financial management, Journal of Small Business Finance, No 1(1)/1991

Bates, J.: The financing of small business, London: Sweet \& Maxwell, 1991

Czepiel A.P.: Pora zacząć mierzyć wpływ funduszy unijnych na gospodarkę,

Oserwatorfinansowy.pl, z dnia 16.05.2016,

https://www.obserwatorfinansowy.pl/forma/rotator/pora-zaczac-mierzyc-wplyw-funduszyunijnych-na-gospodarke/ [dostęp: 18.11.2018]

Czudec A.: Fundusze europejskie a rozwój gospodarczy w skali lokalnej. Nierówności Społeczne a Wzrost Gospodarczy, $\mathrm{nr} 49$ (1)/2017.

European Small Business Finance Outlook. EIF Research \& Market Analysis. Working Paper no. $50 / 2018$

Filipiak B., Ruszała J.: Instytucje otoczenia biznesu. Rozwój, wsparcie, instrumenty, Difin, Warszawa 2009

Gadziński J.: The impact of EU policies on the modernization of transport infrastructure in Poznań and other major Polish cities, [in:] eds. Churski P., Stryjakiewicz T., Bogucki, Poznań -an attempt to assess changes during 10 years of membership in the European Union, Wydawnictwo Naukowe, Poznań 2014

Gorczyńska A.: Wykorzystanie funduszy unijnych w finansowaniu działalności małych i średnich przedsiębiorstw, Ekonomiczne Problemy Usług, nr 111/2014 
Kaczor T., Konrad Soszyński K.: Analiza konsekwencji napływu środków UE na sytuację makroekonomiczną, poziom kursu walutowego i perspektywy wypełnienia kryteriów konwergencji, Ministerstwo Rozwoju Regionalnego, Warszawa 2011

Kaiser R., Prange-Gstöhl H.: The Future of the EU BudgetPerspectives for the Funding of GrowthOriented Policies post-2020, SIEPS nr 6 / 2017

Kehagia A.: The Impact of the UE's Structural and Cohesion Funds: A literature review. The Jean Monnet Papers on Political Economy, 6/2013

Leoński W.: Wpływ Unii Europejskiej na rozwój polskich przedsiębiorstw, Handel Wewnętrzny, nr $3(356) / 2015$

Misiag J., Misiag W., Tomalak M.: Ocena efektywności wykorzystania pomocy finansowej Unii Europejskiej jako instrumentu polityki spójności społeczno-gospodarczej oraz poprawy warunków życia, Wyższa Szkoła Informatyki i Zarządzania, Rzeszów 2013.

Petersen, M.A., Rajan, R.G.: The benefits of lending relationships: Evidence from small business data, Journal of Finance, 49 (1)/1994.

Raport o stanie sektora małych i średnich przedsiębiorstw w Polsce. Red. A. Skowrońska, A.Tarnawa, PARP, Warszawa 2018.

Realizacja programów na lata 2014-2020: umowy według celów tematycznych i kategorii interwencji (stan na 31 października 2018 r. - na podstawie danych z Centralnego Systemu Teleinformatycznego SL2014); (http://www.funduszeeuropejskie.gov.pl [dostęp: 12.11.2018]

Rinaldi, D., Núńez F. J.: The European Fund for StrategicInvestments as a New Type of Budgetary Instrument, CEPS Research Report, No 2017/07, April 2017, Brussels.

Rokhayati I.: Konsept Dynamic Capital Structure Adjustment Model (DCSA) sebagai Penentu Pengambilan Keputusan Struktur Modal pada UMKM, JBIMA, Vol. 6, No. 1/2018

Rossi M.: Capital structure of small and medium enterprises: The Italian case, International Journal of Globalisation and Small Business, nr 6 (2)/2014

Rutkiewicz K.: Znaczenie funduszy europejskich dla rozwoju Polski [w:] Red. M. Winiarski, Gospodarka, innowacje i rozwój, Uniwersytet Wrocławski. Wydział Prawa, Administracji i Ekonomii. Instytut Nauk Ekonomicznych, Wrocław, 2011

Sobolewski D.: A New Approach to Measuring the Development of Micro and Small Enterprises that Use Loan Funds: Financial and Non-financial Aspects, Zeszyty Naukowe WSB w Poznaniu nr $78(1) / 2018$

Sorychta-Wojsczyk B, Musioł-Urbańczyk A.: Analiza wykorzystania funduszy europejskich w Polsce - nowa perspektywa, nowe wyzwania dla rozwoju województw, Organizacja i Zarządzanie nr $1 / 2016$

Sprawozdanie z realizacji w 2014 r. Narodowych strategicznych ram odniesienia na lata 20072013. Ministerstwo infrastruktury i rozwoju. Warszawa 2015

Śliwka M.: Wpływ środków pomocowych z Unii Europejskiej na kondycję gospodarczą Polski w latach 2007-2013, Ekonomia Międzynarodowa, nr 14/2016

Titman, S., Wessels, R.: The determinants of capital structure choice, Journal of Finance, 43(1)/ 1988

van'tHul, R. Determinants of the capital structure of Dutch SMEs. IBA Bachelor Thesis Conference. Eschede The Netherlands. University of Twente. Faculty of Management and Governance, Enschede 2014.

[www.1]: https://www.nbp.pl/home.aspx?f=/statystyka/pieniezna_i_bankowa/naleznosci.html [dostęp: 12.11.2018]

[www.2]: https://www.nbp.pl/home.aspx?f=/systemfinansowy/kredytowy.html [dostęp:

18.11.2018]

[www.3]: https://www.nbp.pl/home.aspx?f=/dzienne/stopy.htm [dostęp: 10.11.2018] 


\section{Summary}

Small and medium-sized enterprises (SMEs), just like other entities in the real sphere, in order to function and develop, must make decisions related to the selection of an appropriate source of financing, taking into account its accessibility and acquisition conditions. The article pointed to the directional research on the impact of EU funds on the economy. The following methods were used in the research: basic methods of time series analysis and index methods for analyzing series, used to determine the increase in the observed phenomenon in the analyzed period compared to the base period (dynamics of variation). An analysis of the allocation of EU funds was made to determine whether they have a significant impact on changes in the value of bank lending in relation to the SME sector? and was it determined whether there were any changes in the quality of the loan portfolio of entities from the SME sector? The analyzes were aimed at bringing the answer to the question of whether EU funds affect the size of lending activities of banks dedicated to SMEs

Keywords: public policy, EU funds, lending, small and medium enterprises

JEL:G21, G23, L38, L57

Informacja o autorach

Dr hab. prof. WSB Marek Dylewski,

Wyższa Szkoła Bankowa w Poznaniu,

Wydział Finansów i Bankowości,

Instytut Finansów, ul. Powstańców WLKP. 5, 61-895

e-mail: marek.dylewski@wsb.poznan.pl,

ORCID: 0000-0003-0168-2798

Prof. zw. dr hab. Beata Zofia Filipiak,

Uniwersytet Szczeciński,

Wydział Nauk Ekonomicznych i Zarządzania,

Instytut Finansów, ul. Mickiewicza 64, 71-101 Szczecin,

e-mail: beata.filipiak@usz.edu.pl,

ORCID 0000-0002-5480-5264 